\title{
Diabetic alteration versus postnatal maturation of rat kidney glycoconjugates - comparative detection by lectin probes
}

\author{
Alexander Lutsyk ${ }^{1}$, Natalya Ambarova1, Volodymyr Antonyuk ${ }^{1,2}$ \\ ${ }^{1}$ Department of Histology and Embryology, Lviv National, Medical University, Lviv, Ukraine \\ ${ }^{2}$ Institute of Cell Biology, National Academy of Sciences of Ukraine, Lviv, Ukraine
}

\begin{abstract}
A panel of ten lectins with different carbohydrate specificities, including three original lectin preparations (MPFA, LABA, and LVA), was used for the investigation of rat kidney glycoconjugate remodeling during postnatal morphogenesis, and the findings were compared with the impairments seen in streptozotocin-induced diabetic nephropathy. Postnatal morphogenesis was accompanied by the accumulation and generalization of DMan, LFuc, and NeuNAc, with simultaneous reduction of DGal and DGalNAc sugar determinants and enhanced heterogeneity of renal microstructure. The most significant redistribution of lectin receptor sites was detected between postnatal days 1 and 20. Beginning from postnatal day 20, renal corpuscles showed selective MPFA, WGA, and RCA labeling. Stabilization of carbohydrate determinants on postnatal day 60 coincided with rat kidney maturity. Diabetic nephropathy induced carbohydrate remodeling reciprocal to that seen during postnatal development, that is, enhanced exposure of DGal and DGalNAc, reduced reactivity of DMan, LFuc, and NeuNAc determinants, and increased lectin labeling of renal tubule brush borders. These results extend the existing data on rearrangement of rat kidney glycoconjugates under physiological and pathological conditions, as well as demonstrate the applicability of three original lectin preparations in glycoconjugate histochemistry. (Folia Histochemica et Cytobiologica 2013, Vol. 51, No. 1, 92-102)
\end{abstract}

Key words: lectin histochemistry, rat kidney, postnatal morphogenesis, streptozotocin-induced diabetic nephropathy

\section{Introduction}

Lectins have been widely used as histochemical reagents for the investigation of cell and tissue glycoconjugates since the early 1970s [1-4]. Although the number of lectins currently exceeds 2000 , purification and characterization of lectins with rare carbohydrate specificities still remain of interest $[4,5]$. A rare lectin from Mycena pura fungus was recently purified and partially characterized in our laboratory [6]. Purification of an $\alpha \mathrm{L}$-fucose-specific lectin from

Correspondence address: A.D. Lutsyk

Department of Histology and Embryology,

Lviv National Medical University, Pekarska St. 69,

79010 Lviv, Ukraine;

tel./fax: + 3803227559 47; e-mail: lutsyk@meduniv.lviv.ua bark of Laburnum anagyroides Medik was reported earlier [7], as well as that of $\alpha \mathrm{D}$-mannose-specific lectin from Leucojum vernum L. bulbs [8]. These three lectin preparations are still poorly defined in the sense of their applicability to developmental morphology and diagnostic histopathologic research.

The kidney is frequently used as the test organ for both purposes, since its glycoconjugates are diverse and abundant, they actively participate in morphogenesis and maintenance of main organ functions, and they are among the first altered under pathological conditions [9-18]. Despite the fact that lectin histochemistry methods were intensively used for the investigations of morphogenic changes in the kidney, as well as diabetes-induced alterations of renal carbohydrate determinants, a comparative study of these two processes has never been accomplished. 
Table 1. Lectin panel used and their carbohydrate specificities

\begin{tabular}{|c|c|c|c|}
\hline No. & Lectin designation, abbreviation & $\begin{array}{l}\text { Specific inhibitory } \\
\text { mono-/disaccharide }\end{array}$ & $\begin{array}{l}\text { Complementary oligo-/ } \\
\text { /polysaccharide }\end{array}$ \\
\hline 1. & Canavalia ensiformis agglutinin, Con A & $\alpha \mathrm{DMan} / \alpha \mathrm{DGlc}$ & Glycogen \\
\hline 2. & Leucojum vernum agglutinin, LVA & $\alpha$ DMan & Fine carbohydrate specificity not defined \\
\hline 3. & Mycena pura fungus agglutinin, MPFA & $\alpha$ DMan, DGlcNAc & $\operatorname{GlcNAc}(\beta 1-2) \operatorname{Man}(\alpha 1-6) /(\alpha 1-2)$ \\
\hline 4. & Laburnum anagyroides bark agglutinin, LABA & $\alpha$ LFuc & $\operatorname{Fuc}(\alpha 1-2) \mathrm{Gal}(\beta 1-4) \mathrm{Glc}$ \\
\hline 5. & Sambucus nigra agglutinin, SNA & NeuNAc $(\alpha 2-6)$ DGal & $\operatorname{NeuNAc}(\alpha 2-6) \operatorname{Gal}(\beta 1-4) \operatorname{GlcNAc}(\beta 1-2)$ \\
\hline 6. & Wheat germ agglutinin, WGA & DGlcNAc $>$ NeuNAc & $\begin{array}{l}\text { NeuNAc(2-6)Gal }(\beta 1-4) \text { GlcNAc, } \\
\text { Man }(\beta 1-4) \text { GlcNAc }(\beta 1-4) \text { GlcNAc }\end{array}$ \\
\hline 7. & Ricinus communis agglutinin, RCA & $\beta \mathrm{DGal}>\mathrm{NeuNAc}$ & NeuNAc(2-6)Gal( $\beta 1-4)$ GlcNAc \\
\hline 8. & Peanut agglutinin, PNA & DGal & $\operatorname{DGal}(\beta 1-3)$ GalNAc \\
\hline 9. & Helix pomatia agglutinin, HPA & $\alpha$ DGalNAc & $\operatorname{GalNAc}(\alpha 1-3)$ GalNAc \\
\hline 10. & Soybean agglutinin, SBA & $\alpha$ DGalNAc $>\beta$ DGalNAc & GalNAc $(\alpha 1-3) \operatorname{Gal}(\beta 1-3)$ GalNAc \\
\hline
\end{tabular}

The aim of the present investigation was to use a set of lectins with different carbohydrate specificities to investigate impairments of rat kidney glycoconjugates in streptozotocin-induced diabetes mellitus (DM), to compare these changes with carbohydrate remodeling taking place during normal postnatal morphogenesis, and, simultaneously, to test the applicability of three original lectin preparations in developmental morphology and experimental histopathology.

\section{Material and methods}

Lectins. Fruit bodies of Mycena pura fungus were collected in September in the mixed forest in the Carpathian Mountains near the town of Skole in the Lviv region (Ukraine). Laburnum anagyroides bark and Leucojum vernum bulbs were collected near Lviv. Purification of lectins was performed as reported earlier [6-8]. Three original lectin preparations (MPFA, LABA, and LVA) were supplemented with 7 standard lectins of different carbohydrate specificities (Table 1). All lectins used were prepared in the laboratory (Lectinotest, Lviv, Ukraine) by Dr. V. Antonyuk.

The purity of Mycena pura lectin was estimated by diskelectrophoresis in $10 \%$ polyacrylamide gels (PAGE) in an alkaline buffer system ( $\mathrm{pH}$ 8.6) [19]. Electrophoresis was performed in two parallel tubes. One was stained by Coumassie R-250, and the second tube was cut into 5-mm-long pieces. Polyacrylamide gel pieces were then homogenized

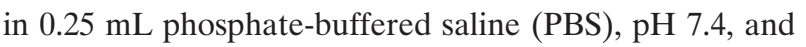
their hemagglutination titers were examined (Figure 1).

The molecular masses of MPFA, LABA, and LVA polypeptide chains were estimated by PAGE in $15 \%$ polyacrylamide, supplemented with $0.1 \%$ sodium dodecyl-sulphate [19]. A mixture of proteins with known molecular

\begin{tabular}{|c|c|c|}
\hline $\begin{array}{l}\text { No of } \\
\text { fraction }\end{array}$ & $\begin{array}{l}\text { Rabbit erythrocyte } \\
\text { agglutination titer }\end{array}$ & $\begin{array}{l}\text { Disk-electrophoresis } \\
\text { lectin in } 10 \% \text { PAAG, } \\
\text { pH } 8,6\end{array}$ \\
\hline & & -Start \\
\hline 1 & $1: 4$ & \\
\hline 2 & $1: 4$ & \\
\hline 3 & $1: 64$ & 물 \\
\hline 4 & $1: 1$ & \\
\hline 5 & - & $x=$ \\
\hline 6 & - & 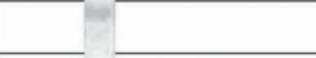 \\
\hline 7 & - & \\
\hline 8 & - & 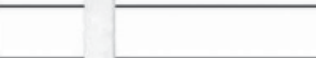 \\
\hline 9 & - & 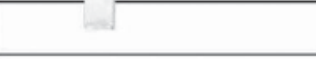 \\
\hline
\end{tabular}

Figure 1. Electrophoretic purity of lectin from the fruit body of Mycena pura fungus (MPFA). Lectin electrophoresis was performed in $10 \%$ PAAG, $\mathrm{pH} 8.6$

masses (Fermentas, Olayne, Latvia) was used as a standard (Figure 2). The carbohydrate specificities of lectins were tested by inhibition of hemagglutination with appropriate mono- or disaccharides as described earlier [7]. Lectinhorseradish peroxidase conjugates were obtained using the method of Nakane and Kawaoi [20], with some modifications [21].

Animals. The study was performed on 78 male Wistar rats, subdivided into a control group of 15 animals and 9 experimental groups: 4 groups of different ages $(1,20,40$, and 120 postnatal days, $\mathrm{n}=7$ in each group), and 5 groups at different stages of experimental DM (days 14, 30, 40, 60, and 80 after streptozotocin injection, $\mathrm{n}=7$ in each group). 


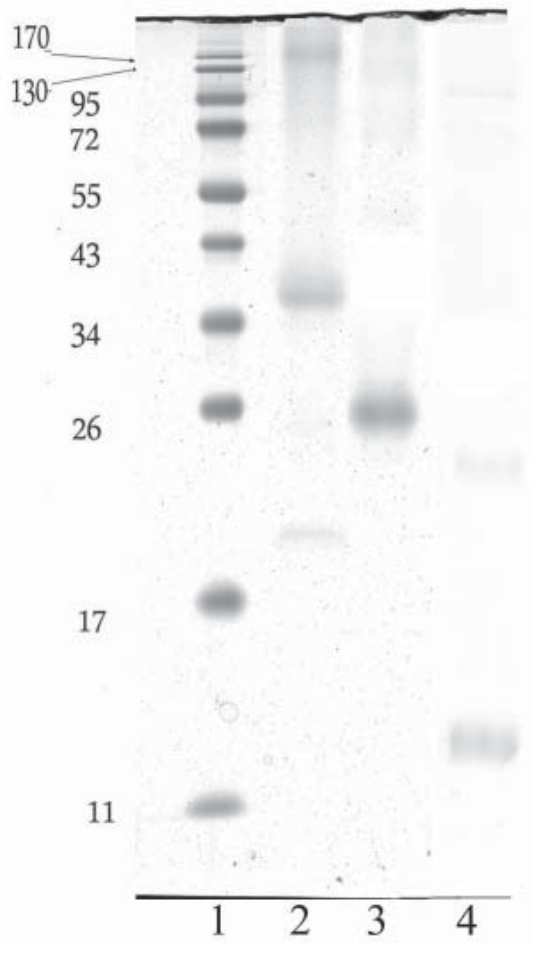

Figure 2. Electrophoresis of lectin preparations in $15 \%$ PAGE supplemented with $0.1 \%$ sodium dodecyl-sulphate. Lanes: 1, protein markers with known molecular mass; 2, Mycena pura fungus agglutinin (MPFA); 3, Laburnum anagyroides bark agglutinin (LABA); 4, Leucojum vernum agglutinin (LVA)

Experimental DM was induced in rats weighing 120 $-140 \mathrm{~g}$ by a single intra-abdominal injection of $70 \mathrm{mg} / \mathrm{kg}$ streptozotocin (Sigma, St. Louis, MO, USA) dissolved in $0.1 \mathrm{M}$ citrate buffer, $\mathrm{pH} 4.2$ [22]. Control rats were given a single intra-abdominal injection of $1 \mathrm{~mL}$ citrate buffer, $\mathrm{pH}$ 4.2. Development of DM was monitored by measuring glucose serum concentration with the gluco-oxidase test (LaChema, Prague, Czech Republic) according to the manufacturer's instructions. A blood glucose level of 10$-18 \mathrm{mMol} / \mathrm{L}$ was taken as the evidence of DM development.

The investigation was carried out according to the ethical criteria for the use and handling of laboratory animals established by Lviv National Medical University in accor- dance with the "General ethical principles on experiments with animals" of the $1^{\text {st }}$ National Congress on Bioethics (Kiev, 2001) and in compliance with the National Institutes of Health (NIH) Guide for the Care and Use of Laboratory Animals (1996).

Tissue samples. Animals were sacrificed by diethyl ether narcosis overdose with subsequent decapitation. The kidneys were removed from their capsules, sectioned centromedially, fixed in $4 \%$ neutral buffered formalin overnight, and embedded in paraffin wax according to the standard protocol. For general morphology studies, 5- to 7- $\mu \mathrm{m}$-thick sections were stained with hematoxylin and eosin. Lectin histochemistry investigations were conducted using the peroxidase-diaminobenzidine visualization protocol as described elsewhere [23].

Microscopic investigation was performed using a Zeiss $\mathrm{Ng}$ microscope (Carl Zeiss, Jena, Germany) equipped with a Canon IXUS 700 digital camera (Canon, Tokyo, Japan). For semiquantitative evaluation of lectin binding, two investigators performed the analysis independently, blinded to lectin type. Binding intensity was evaluated using a semiquantitative scale as follows: ++ strong, + positive, and - negative labeling (Table 5).

\section{Results}

\section{Lectin specification}

The main electrophoretic characteristics of the three original lectin preparations (MPFA, LABA, and LVA) are shown in Figures 1 and 2. The results of these lectins' interactions with human and animal erythrocytes are presented in Table 2 , with mono- and disaccharides in Table 3, and with polysaccharides and glycoproteins in Table 4.

\section{Postnatal morphogenesis}

In the kidneys of newborn rats, lectin receptor sites were localized predominantly on the luminal surface and in the apical portions of S-shaped bodies, the terminal ampullae (Figure 3A, 5A), and on collecting

Table 2. Minimal concentration of lectin, that produced erythrocyte agglutination (in $\mu \mathrm{g} / \mathrm{mL}$ )

\begin{tabular}{|l|c|c|c|c|c|c|c|c|c|}
\hline \multirow{2}{*}{ Source of lectin } & \multicolumn{9}{|c|}{ Type of erythrocytes } \\
\cline { 2 - 13 } & \multicolumn{3}{|c|}{ Human } & Sheep & Goat & Cow & Horse & Rabbit & Dog \\
\cline { 2 - 13 } & O (I) & A (II) & B (III) & & & & & & \\
\hline Mycena pura & 312 & 156 & 312 & 312 & 1250 & 2500 & 39 & 39 & 9.7 \\
Laburnum anagyroides bark & $4.9^{*}$ & $78^{*}$ & $156^{*}$ & - & - & - & - & 1250 & n.d. \\
Leucojum vernum & - & - & - & 10000 & 1250 & - & - & 4.9 & n.d. \\
\hline
\end{tabular}

Note: dash means absence of agglutination at concentration of lectins $10,000 \mu \mathrm{g} / \mathrm{mL}$; *For Laburnum anagyroides bark lectin minimal agglutinating concentration is different for various donors among human blood groups 
Table 3. Interaction of MPFA, LABA, and LVA with some mono- and disaccharides

\begin{tabular}{|l|l|c|c|c|}
\hline No. & Carbohydrate & \multicolumn{3}{|c|}{$\begin{array}{c}\text { Minimum hapten concentration for } \\
\text { inhibition of hemagglutination (mM) }\end{array}$} \\
\hline & & MPFA & LABA & LVA \\
\hline 1. & D-glucose & 100 & - & - \\
\hline 2. & L-fucose & - & 0.39 & - \\
\hline 3. & $\alpha$-methyl-L-fucopyranoside & - & 0.1 & - \\
\hline 4. & 4-nitrophenyl- $\alpha$-L-fucopyranoside & - & 0.01 & 100 \\
\hline 5. & D-mannose & 50 & 100 & 50 \\
\hline 6. & $\alpha$-methyl-D-mannopyranoside & 25 & 50 & - \\
\hline 7. & D-fructose & - & - & 12.5 \\
\hline 8. & Melibiose (Gal $\alpha 1,6$ Glc) & 100 & - & - \\
\hline 9. & Gentiobiose $(G l c \beta 1,6 G l c)$ & 100 & - & 100 \\
\hline 10. & Turanose $(G l c \beta 1,3$ Fru) & 100 & - & - \\
\hline 11. & Glucose-6-phosphate dipotassium salt & & - & \\
\hline
\end{tabular}

Note: dash means absence of interaction at concentration of $100 \mathrm{mM}$. N-acetyl-D-glucosamine, N-acetyl-D-galactosamine, D-galactose, D-ribose, $\alpha$-methyl-D-glucopyranoside, cellobiose (Glc $\beta 1,4 \mathrm{Glc})$, maltose (Glca1,4Glc), trehalose (Glc $\beta 1,1 \mathrm{Glc}), \beta$-methyl-D-xylopyranoside are not included to the list, since they do not interact with studied lectins in concentration $100 \mathrm{mM}$ and less

Table 4. Lectin interactions with polysaccharides and glycoproteins

\begin{tabular}{|c|c|c|c|c|}
\hline \multirow[t]{2}{*}{ No. } & \multirow[t]{2}{*}{ Polysaccharide or glycoprotein } & \multicolumn{3}{|c|}{$\begin{array}{l}\text { Minimal concentration of glycoproteins } \\
\text { for inhibition of hemagglutination }\end{array}$} \\
\hline & & MPFA & LABA & LVA \\
\hline 1. & Transferrin & $0.25 \%$ & - & - \\
\hline 2. & Bovine thyroglobulin & $0.125 \%$ & - & $0.5 \%$ \\
\hline 3. & Alkaline phosphatase from calf small intestine & $0.002 \%$ & $0.25 \%$ & - \\
\hline 4. & Orosomucoid & $0.125 \%$ & $1 \%$ & - \\
\hline 5. & Ovomucoid & $0.06 \%$ & - & $1 \%$ \\
\hline 6. & Asialo-ovomucoid & $0.015 \%$ & - & - \\
\hline 7. & Ovine submaxillary mucin & $0.125 \%$ & n.d. & $0.25 \%$ \\
\hline 8. & Bovine submaxillary mucin & $1 \%$ & $0.25 \%$ & - \\
\hline 9. & Bovine submaxillary mucin desialised & $0.5 \%$ & $0.008 \%$ & - \\
\hline 10. & Human immunoglobulin $\mathrm{G}$ & - & - & - \\
\hline 11. & $\alpha_{2}$-macroglobulin & $1 \%$ & - & - \\
\hline 12. & Blood group specific substance $\mathrm{H}, 1 \%$ & $0.125 \%$ & $0.0004 \%$ & - \\
\hline 13. & Blood group specific substance A, $1 \%$ & $0.125 \%$ & $0.25 \%:$ & - \\
\hline 14. & Blood group specific substance B, $1 \%$ & $0.25 \%$ & $0.25 \%$ & - \\
\hline 15. & Ovalbumin & $0.125 \%$ & - & - \\
\hline 16. & Pig liver glycogen, $1 \%$ & $0.5 \%$ & - & - \\
\hline 17. & Yeast mannan, $1 \%$ & - & - & $0.03 \%$ \\
\hline 18. & Starch, $1 \%$ & $1 \%$ & - & $1 \%$ \\
\hline
\end{tabular}

Note: dash means absence of interaction at concentration of $1 \%$

duct cells (Figure 4A). From postnatal day 20, selective labeling of the renal corpuscle filtration membrane with MPFA, WGA, and RCA was detected (Table 5,
Figures 3B, C, 6C). It is noteworthy that, of all of the lectins used, MPFA appeared to be the most selective early marker of the developing renal corpuscles. 
Table 5. Age-related and diabetes-induced effects on lectin binding to renal microstructures

\begin{tabular}{|c|c|c|c|c|c|c|c|c|c|}
\hline \multirow[t]{2}{*}{ No. } & \multirow{2}{*}{$\begin{array}{l}\text { Lectin, its } \\
\text { carbohydrate } \\
\text { specificity }\end{array}$} & \multirow{2}{*}{$\begin{array}{l}\text { Experimental } \\
\text { group of animals }\end{array}$} & \multicolumn{7}{|c|}{ Renal structures } \\
\hline & & & Podocytes & $\begin{array}{l}\text { Mesangial } \\
\text { cells }\end{array}$ & $\begin{array}{l}\text { Filtration } \\
\text { membrane }\end{array}$ & $\begin{array}{c}\text { Renal } \\
\text { corpuscle }\end{array}$ & $\begin{array}{c}\text { Proximal } \\
\text { tubule } \\
\text { (brush } \\
\text { border) }\end{array}$ & $\begin{array}{l}\text { Distal } \\
\text { tubule }\end{array}$ & $\begin{array}{c}\text { Collecting } \\
\text { duct }\end{array}$ \\
\hline 1. & $\begin{array}{l}\text { Con A, } \\
\alpha \text { DMan, } \\
\alpha \text { DGlc }\end{array}$ & $\begin{array}{l}\text { Postnatal day } 20 \\
\text { Postnatal day } 120 \\
\text { Diabetes mellitus }\end{array}$ & $\begin{array}{c}+ \\
++ \\
-\end{array}$ & $\begin{array}{c}+ \\
++ \\
-\end{array}$ & $\begin{array}{c}+ \\
++ \\
+\end{array}$ & $\begin{array}{l}++ \\
++ \\
-\end{array}$ & $\begin{array}{c}+ \\
++ \\
-\end{array}$ & $\begin{array}{c}+ \\
++ \\
+\end{array}$ & $\begin{array}{c}+ \\
++ \\
+\end{array}$ \\
\hline 2. & $\begin{array}{l}\text { LVA, } \\
\alpha \text { DMan }\end{array}$ & $\begin{array}{l}\text { Postnatal day } 20 \\
\text { Postnatal day } 120 \\
\text { Diabetes mellitus }\end{array}$ & $\begin{array}{c}+ \\
++ \\
+\end{array}$ & $\begin{array}{c}+ \\
++ \\
+\end{array}$ & $\begin{array}{c}+ \\
++ \\
+\end{array}$ & $\begin{array}{l}+ \\
++ \\
+\end{array}$ & $\begin{array}{l}+ \\
++ \\
+\end{array}$ & $\begin{array}{c}+ \\
++ \\
+\end{array}$ & $\begin{array}{c}+ \\
++ \\
+\end{array}$ \\
\hline 3. & $\begin{array}{l}\text { MPFA, } \\
\text { DMan, } \\
\text { DGlcNAc }\end{array}$ & $\begin{array}{l}\text { Postnatal day } 20 \\
\text { Postnatal day } 120 \\
\text { Diabetes mellitus }\end{array}$ & $\begin{array}{c}+ \\
++ \\
+\end{array}$ & $\begin{array}{c}+ \\
++ \\
+\end{array}$ & $\begin{array}{c}+ \\
++ \\
+\end{array}$ & $\begin{array}{l}++ \\
++ \\
++\end{array}$ & $\begin{array}{l}++ \\
++ \\
++\end{array}$ & $\begin{array}{c}++ \\
++ \\
+\end{array}$ & $\begin{array}{c}+ \\
++ \\
+\end{array}$ \\
\hline 4. & $\begin{array}{l}\text { LABA, } \\
\alpha \text { LFuc }\end{array}$ & $\begin{array}{l}\text { Postnatal day } 20 \\
\text { Postnatal day } 120 \\
\text { Diabetes mellitus }\end{array}$ & $\begin{array}{c}+ \\
++ \\
-\end{array}$ & $\begin{array}{c}+ \\
++ \\
+\end{array}$ & $\begin{array}{l}++ \\
++ \\
-\end{array}$ & $\begin{array}{l}++ \\
++ \\
-\end{array}$ & $\begin{array}{c}+ \\
++ \\
+\end{array}$ & $\begin{array}{c}+ \\
++ \\
+\end{array}$ & $\begin{array}{c}+ \\
++ \\
+\end{array}$ \\
\hline 5. & $\begin{array}{l}\text { SNA, } \\
\text { NeuNAc } \\
(\alpha 2-6) \text { DGal }\end{array}$ & $\begin{array}{l}\text { Postnatal day } 20 \\
\text { Postnatal day } 120 \\
\text { Diabetes mellitus }\end{array}$ & $\begin{array}{l}- \\
+ \\
+\end{array}$ & $\begin{array}{c}+ \\
++ \\
+\end{array}$ & $\begin{array}{c}- \\
++ \\
-\end{array}$ & $\begin{array}{c}+ \\
++ \\
+\end{array}$ & $\begin{array}{c}+ \\
++ \\
+\end{array}$ & $\begin{array}{c}+ \\
++ \\
-\end{array}$ & $\begin{array}{c}+ \\
++ \\
+\end{array}$ \\
\hline 6. & $\begin{array}{l}\text { WGA, } \\
\text { DGlcNAc } \\
>\text { NeuNAc }\end{array}$ & $\begin{array}{l}\text { Postnatal day } 20 \\
\text { Postnatal day } 120 \\
\text { Diabetes mellitus }\end{array}$ & $\begin{array}{c}+ \\
++ \\
+\end{array}$ & $\begin{array}{c}+ \\
++ \\
+\end{array}$ & $\begin{array}{l}++ \\
++ \\
+\end{array}$ & $\begin{array}{l}++ \\
++ \\
+\end{array}$ & $\begin{array}{c}+ \\
++ \\
+\end{array}$ & $\begin{array}{c}+ \\
++ \\
-\end{array}$ & $\begin{array}{c}+ \\
++ \\
+\end{array}$ \\
\hline 7. & $\begin{array}{l}\text { RCA, } \\
\beta \text { DGal } \\
>\text { NeuNAc }\end{array}$ & $\begin{array}{l}\text { Postnatal day } 20 \\
\text { Postnatal day } 120 \\
\text { Diabetes mellitus }\end{array}$ & $\begin{array}{c}+ \\
++ \\
+\end{array}$ & $\begin{array}{c}+ \\
++ \\
+\end{array}$ & $\begin{array}{l}+ \\
++ \\
++\end{array}$ & $\begin{array}{c}+ \\
++ \\
+\end{array}$ & $\begin{array}{c}+ \\
++ \\
+\end{array}$ & $\begin{array}{c}+ \\
++ \\
+\end{array}$ & $\begin{array}{c}+ \\
++ \\
+\end{array}$ \\
\hline 8. & $\begin{array}{l}\text { PNA, } \\
\text { DGal }\end{array}$ & $\begin{array}{l}\text { Postnatal day } 20 \\
\text { Postnatal day } 120 \\
\text { Diabetes mellitus }\end{array}$ & $\begin{array}{l}+ \\
+ \\
++\end{array}$ & $\begin{array}{l}++ \\
+ \\
++\end{array}$ & $\begin{array}{l}+ \\
+ \\
++\end{array}$ & $\begin{array}{l}+ \\
+ \\
++\end{array}$ & $\begin{array}{c}++ \\
+ \\
++\end{array}$ & $\begin{array}{l}+ \\
+ \\
++\end{array}$ & $\begin{array}{l}+ \\
+ \\
++\end{array}$ \\
\hline 9. & $\begin{array}{l}\text { HPA, } \\
\alpha \text { DGal NAc }\end{array}$ & $\begin{array}{l}\text { Postnatal day } 20 \\
\text { Postnatal day } 120 \\
\text { Diabetes mellitus }\end{array}$ & $\begin{array}{l}+ \\
+ \\
+\end{array}$ & $\begin{array}{l}+ \\
+ \\
++\end{array}$ & $\begin{array}{c}++ \\
+ \\
++\end{array}$ & $\begin{array}{c}++ \\
+ \\
++\end{array}$ & $\begin{array}{l}++ \\
+ \\
++\end{array}$ & $\begin{array}{c}++ \\
+ \\
++\end{array}$ & $\begin{array}{l}++ \\
+ \\
++\end{array}$ \\
\hline 10. & $\begin{array}{l}\text { SBA, } \\
\alpha \text { DGalNAc } \\
>\beta \text { DGalNAc }\end{array}$ & $\begin{array}{l}\text { Postnatal day } 20 \\
\text { Postnatal day } 120 \\
\text { Diabetes mellitus }\end{array}$ & $\begin{array}{l}++ \\
+ \\
++\end{array}$ & $\begin{array}{l}++ \\
+ \\
++\end{array}$ & $\begin{array}{c}++ \\
+ \\
++\end{array}$ & $\begin{array}{l}+ \\
- \\
+\end{array}$ & $\begin{array}{l}++ \\
+ \\
++\end{array}$ & $\begin{array}{l}+ \\
+ \\
++\end{array}$ & $\begin{array}{l}++ \\
+ \\
++\end{array}$ \\
\hline
\end{tabular}

Binding intensity: ++ strong; + positive; - lack of binding

Kidneys on postnatal days 60 and 120 showed heterogeneity of renal tubules: outer medulla tubules preferentially reacted with WGA and RCA (Figure $6 \mathrm{C}, \mathrm{D})$; cells of cortical tubules displayed selective reactivity with SBA and HPA; and collecting duct cells exposed rather mosaic reactivity with SNA. Another characteristic, age-dependent phenomenon, concerned the nuclei of podocytes, mesangiocytes, endotheliocytes, and renal tubule epithelial cells: their lectin reactivity shifted from negative on postnatal days 1 and 20 to positive labeling with Con A, LVA, MPFA, LABA, SNA, and PNA on day 60, and to a strong reactivity with these same lectins on postnatal day 120 (Figures 4A, B, C, 6A, B). Semiquantitative evaluation of lectin binding showed increased exposure of Con A, LVA, MPFA, LABA, SNA, WGA, and RCA receptor sites in association with the decrease of PNA, HPA, and SBA binding during subsequent phases of postnatal development. Prominent morphogenesis-related redistribution of lectin receptor sites ceased on day 60; at this time, the histotopography of lectin labels corresponded to that of day 120.

\section{Diabetic nephropathy}

Streptozotocin injection induced significant redistribution of lectin receptor sites in all experimental groups of animals. In detail, reductions of Con A, LVA, MPFA, LABA, SNA, WGA, and RCA binding were accompanied by the enhanced exposure of PNA, HPA, and SBA receptor sites (Table 5, Figures 3D, $4 \mathrm{D}, 5 \mathrm{D}, 6 \mathrm{D})$. A considerable increase in the reactivity of brush border glycoconjugates was detected in the proximal and distal tubules, as well as of the luminal surface of collecting duct cells, with most of 

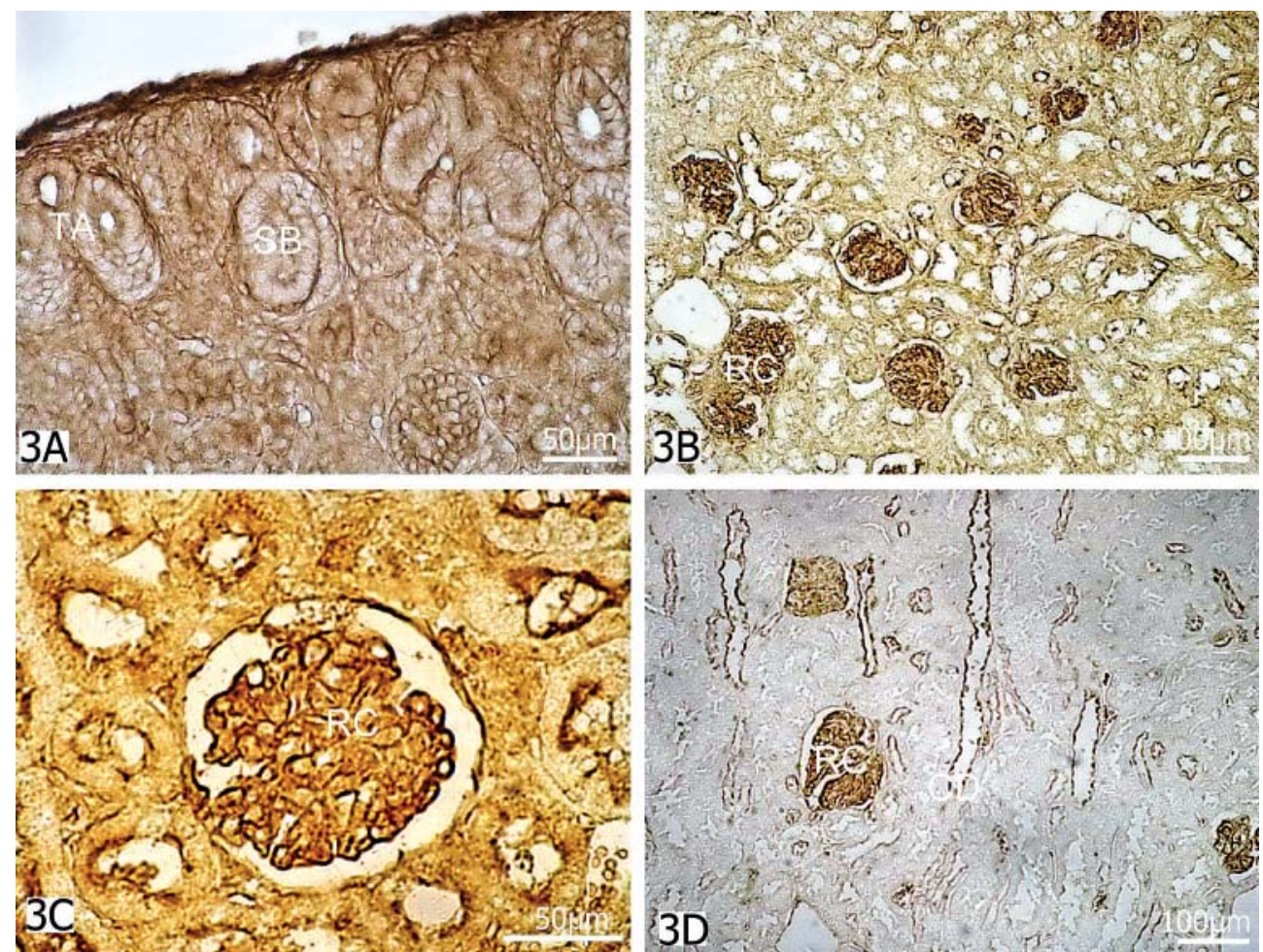

Figure 3. Redistribution of MPFA receptor sites in rat kidney under experimental conditions. (A) Postnatal day 1: on the moderately positive background of renal parenchyma, intensive lectin binding to luminal surface and apical cytoplasm of S-shaped bodies (SB) and terminal ampullae (TA) cells. (B) Postnatal day 20: strong labeling of renal corpuscles (RC), with moderate reactivity of renal tubules. (C) Postnatal day 120: strong reactivity of renal corpuscle (RC) and of adjacent proximal tubules' brush border, with cytoplasmic glycoconjugates of tubular cells faintly positive. (D) Post-streptozotocin day 30: in comparison with (C), loss of lectin binding to renal parenchyma, with strong reactivity of renal corpuscles (RC), brush border of renal tubules, and collecting duct $(\mathrm{CD})$ cells. Objective magnification: $\times 40(\mathrm{~A}), \times 20(\mathrm{~B}, \mathrm{D}), \times 60(\mathrm{C})$

the lectins used. Development of diabetic nephropathy had no consistent effects on the selectivity of filtration membrane labeling with MPFA, WGA, and RCA (Figures 3C, D, 6C, D). It is noteworthy, that significant histopathologic changes were identified by means of lectin histochemistry already on day 14 post streptozotocin injection, being supplemented by other morphological manifestations en route of diabetic progression.

\section{Discussion}

\section{Developmental morphology}

The data presented demonstrate increases in Con A, LVA, MPFA, LABA, SNA, WGA, and RCA reactivities with the developing renal microstructure in association with decreased PNA, HPA, and SBA labeling. It is known that Con A possesses the highest affinity to biantennary oligosaccharides with a tri-mannoside core and BDGlcNAc as terminus. Attachment of DGal and NeuNAc residues to the tri-mannoside core inhibits binding affinity [24]. For LVA, the high- est inhibitory activity is documented with oligosaccharides containing terminal $\operatorname{Man}(\alpha 1-3)$ Man residues, while Con A prefers Man( $\alpha 1-2)$ Man. MPFA, which can also be considered as mannose-specific lectin, in contrast to Con A and LVA, in our preliminary studies demonstrated very high affinity to alkaline phosphatase from calf intestine (Table 4). We presume that an important role in MPFA binding to glycoproteins is played by GlcNAc $\beta(1-2) \operatorname{Man} \alpha(1-6)$ or GlcNAc $\beta(1-2) \operatorname{Man} \alpha(1-2)$ sugar moieties, which do not obligatorily take terminal positions [6].

Enhancement of Con A, LVA, and MPFA binding to rat kidney glycoconjugates during postnatal morphogenesis encompasses the accumulation of mannose-rich structural components. It also becomes obvious that all of the above lectins do not possess sufficient selectivity to discriminate structure-specific renal glycoconjugates. However, MPFA proved to be the most selective early label of the developing renal corpuscles. Our recent data on the specificity of this lectin binding extend previous observations concerning its reactivity with alkaline phosphatase and demonstrate its binding to a wide diversity of com- 

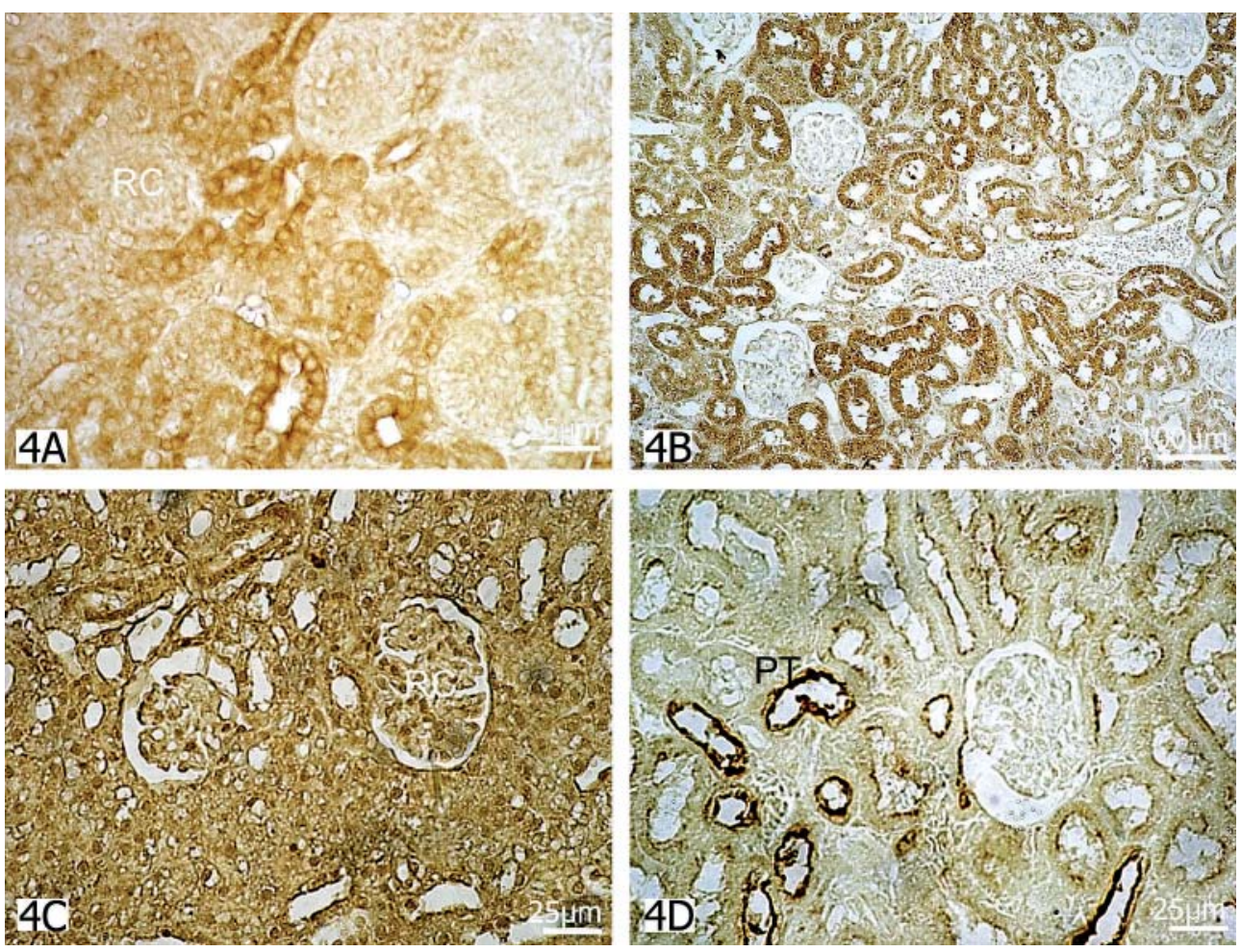

Figure 4. Histotopography of fucosylated glycopolymers as detected by LABA binding. (A) Postnatal day 1: reactivity within the cytoplasm of terminal ampullae cells, with developing renal corpuscles (RC) faintly positive. (B) Postnatal day 60: strong positive cytoplasmic and nuclear glycoconjugates of tubular epitheliocytes, with renal corpuscles (RC) faintly reactive. (C) Postnatal day 120: in comparison with (A) and (B), more intensive lectin binding to nuclear and cytoplasmic glycoconjugates of renal corpuscles (RC) and tubular cells. (D) Post-streptozotocin day 80: in comparison with (C), significantly decreased reactivity of renal parenchyma, with enhanced labeling of proximal tubules (PT) brush border. Objective magnification: $\times 40(\mathrm{~A}, \mathrm{C}, \mathrm{D})$, and $\times 20(\mathrm{~B})$

plex type renal glycoconjugates with DMan/DGlc and DGlcNAc sugar determinants.

The carbohydrate specificity of LABA, similar to that of Tetragonolobus purpureus agglutinin (TPA), is directed towards LFuc residues of glycoconjugates. Complex type biantennary oligosaccharides with terminal LFuc $\alpha$ (1-2)Gal strongly inhibit LABA agglutination activity. Interestingly, oligosaccharides with LFuc $\alpha$ (1-3)Gal terminus do not possess inhibitory activity [25]. Development-related enhancement of LABA reactivity apparently indicates postnatal accumulation of LFuc $\alpha$ (1-2)Gal sugar determinants in renal microstructures.

Decreased PNA, HPA, and SBA labeling accompanied by the enhanced exposure of SNA, WGA, and RCA receptor sites is most likely related to masking of DGal and DGalNAc by NeuNAc residues, a maturation-related change in glycoconjugate processing, which is quite common in mammalian tissues $[2,3]$. The present results are in agreement with and extend earlier observations of Holthofer et al. [13], who reported progressive sialylation with simultaneous re- duction of DGalNAc determinants during renal development in rats. Similarly, enhanced fucosylation and sialylation patterns in association with reduced DGal and DGalNAc content were detected in the developing mouse kidney $[12,14]$.

The most significant age-related redistribution of lectin receptor sites was detected between postnatal days 1 and 20. Among the other representative signs of kidney maturation was strong reactivity of previously non-reactive renal corpuscles with MPFA, WGA, and RCA. These results apparently demonstrate an important role of DGlcNAc and NeuNAc sugar determinants in the developing filtration barrier of a rat. Although the earliest signs of renal corpuscle lectin reactivity in the present study were first detected in 20-day-old rats, it should be noted that Zuber et al. [16] reported SNA labeling of rat kidney corpuscles already on postnatal day 5, and Hanai et al. [14] detected lectin binding to murine renal corpuscles still earlier, on postnatal day 2 . These results apparently indicate the ongoing process of kidney maturation, which, according to our observations, lasts at least until postnatal day 60 . 

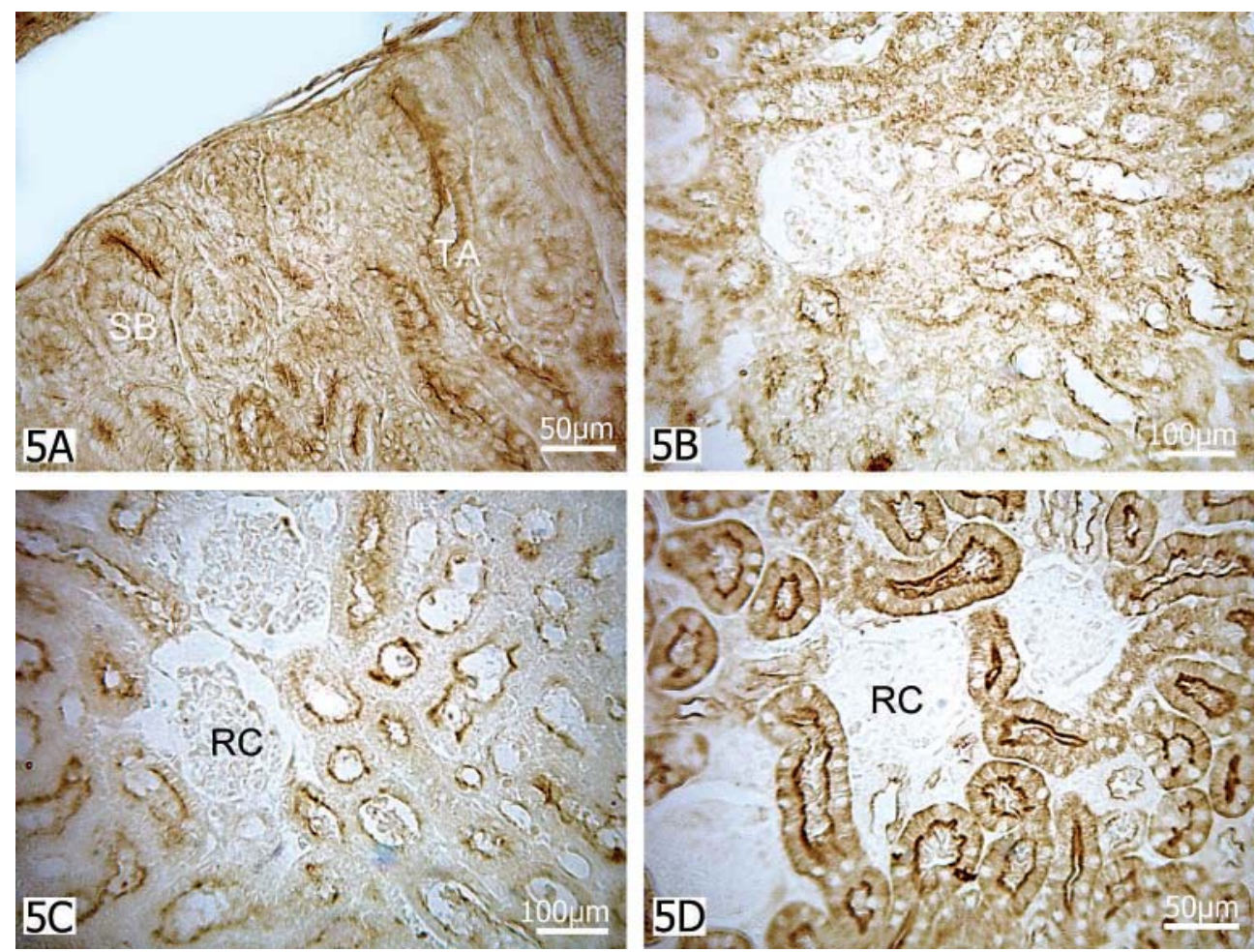

Figure 5. Redistribution of SBA receptor sites during postnatal morphogenesis (A, B, C) and in diabetes-affected (D) rat kidney. (A) Postnatal day 1: lectin labeling restricted to luminal surface and apical portions of the cells forming S-shaped bodies (SB) and terminal ampullae (TA). (B) Postnatal day 20: trace reactivity of renal tubule brush border and nuclear glycoconjugates. (C) Postnatal day 120: in comparison with (A), reduced reactivity of tubular cells luminal surface and apical cytoplasm, with the renal corpuscle (RC) not reactive. (D) Post-streptozotocin day 14: in comparison with (C), enhanced lectin labeling of renal tubules brush border and cytoplasmic glycoconjugates, with epithelial cell nuclei and renal corpuscles $(\mathrm{RC})$ not reactive. Objective magnification: $\times 40$

The present data on shifting of the lectin reactivity of renal tubule epithelial cell nuclei from completely negative in newborn rats to strongly positive on postnatal day 120 correlate with the earlier observations of Schulte and Spicer [9], who detected PNA binding to the nuclei of renal tubule epithelium in adult rats. Similar shifting of nuclear reactivity with fucose-specific lectin UEA-I was also seen during postnatal development of mouse kidney [14]. Moreover, Roth [26], using electron microscopy, demonstrated Con A binding to condensed and nucleolar-associated chromatin of adult rat hepatocytes. The present findings of nuclear lectin reactivity apparently relate to the progress of nuclear heterochromatinization which becomes completed in rat kidney by postnatal day 120 .

\section{Diabetic nephropathy}

Lectin histochemistry revealed that DM induced significant remodeling of rat kidney glycoconjugates. In general, it was opposite to the glucoconjugates pattern observed during normal postnatal development, with enhanced exposure of PNA, HPA, and SBA receptor sites in association with decreased Con A, LVA, MPFA, LABA, SNA, WGA, and RCA binding. It is known that oligosaccharides are much stronger inhibitors of lectin hemagglutinating activity than monosaccharides. Similar structure of di- and tri-saccharides can be discriminated with regard to lectin binding affinities [2]. Since the primary structure of renal glycoconjugate oligosaccharide chains has not as yet been described, the interpretation of the present results can only be hypothetical.

In detail, the affinities of PNA, HPA, and SBA are directed towards DGal and DGalNAc sugar residues. PNA is a rather unique lectin in the sense of its selective binding to DGal and its complete lack of interaction with DGalNAc. The highest affinity of PNA was documented with T-antigen (Gal $\beta 1$-3Gal-NAc) and several related oligosaccharides [27]. On the other hand, the HPA combining site is directed exclusively towards the terminal non-reducing $\alpha \mathrm{DGal}-$ -NAc residues. Galactose, mannose, glucose, $\mathrm{N}$-acetyl-D-galactosamine, and $\mathrm{N}$-acetyl-D-glucosamine 

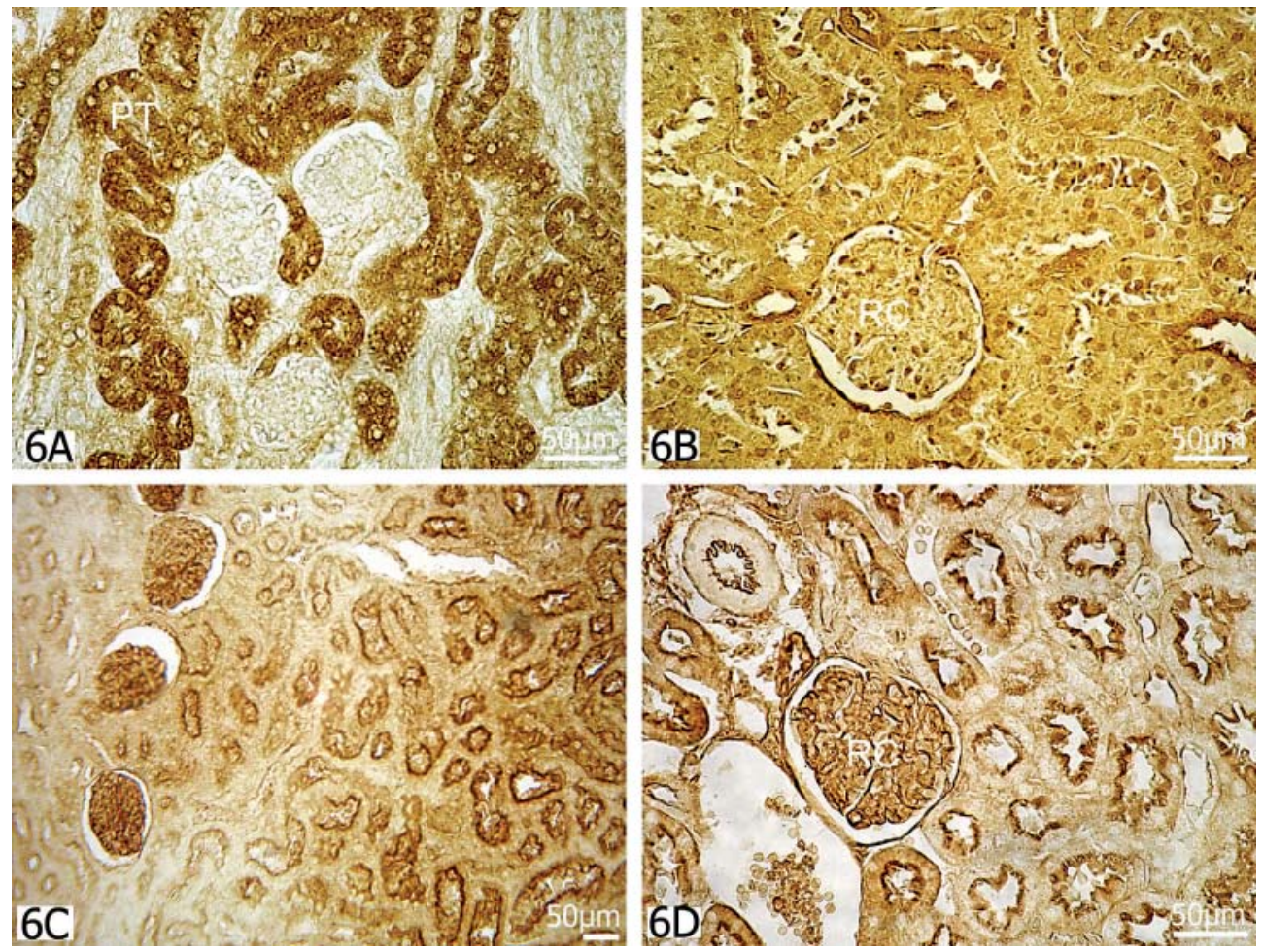

Figure 6. Selectivity of lectin binding to rat kidney microstructures. (A) Postnatal day 1: negative image of the developing renal corpuscles and epithelial cell nuclei on strongly positive background of proximal tubule (PT) cytoplasmic glycoconjugates as displayed by LVA labeling. (B) Postnatal day 120: in comparison with (A), strong LVA reactivity of nuclearassociated glycopolymers within renal tubules and renal corpuscle (RC) cells. (C) Postnatal day 60: predominant RCA binding to the brush border of medullary tubules and to renal corpuscles, with adjoining cortical tubules only faintly positive. (D) Post-streptozotocin day 14: intensive RCA reactivity of renal corpuscle (RC) filtration membrane and of tubular cells brush border. Objective magnification: $\times 40(\mathrm{~A}, \mathrm{~B}, \mathrm{D})$, and $\times 20(\mathrm{C})$

do not inhibit HPA activity. The best known HPA inhibitor is Forssman antigen, containing a non-reducing GalNAc $\alpha(1-3)$ GalNAc terminus. SBA binds both DGal and DGalNAc, though the inhibitory activity of GalNAc $\alpha(1-3)$ Gal disaccharide is much higher [28].

SNA hemagglutinating activity is inhibited by DGal and DGalNAc, as well as by a variety of oligosaccharides containing these residues in terminal positions, in concentrations of 10-30 mM [29]. However, the inhibitory potential of oligosaccharides with the Neu-NAc $\alpha(2-6)$ Gal terminus exceed that of DGal by 1,600 $-10,000$ times [29]. RCA interacts with DGal, the inhibitory activity of Gal $\beta(1-4)$ GlcNAc disaccharide is 15 times higher, and a still higher affinity is possessed by the trisaccharide NeuNAc $\alpha(2-6) G a l \beta(1-4) G l c$. The interaction of WGA with carbohydrates is directed towards the disaccharide $\operatorname{Man} \beta(1-4)$ GlcNAc $\beta 1$-Asp, though this lectin molecule consists also of a combining site for the NeuNAc terminus [30]. As can be seen, a crucial role for SNA, RCA, and WGA binding to tissue glycoconjugates is played by NeuNAc residues in different stereoisomeric positions.
Despite the fact that the biological background of glycoconjugate remodeling during postnatal development and in diabetic nephropathy is completely different, it is likely that oligosaccharide processing under these two conditions shares certain common steps. From our recent findings of reciprocal tendencies in the rearrangement of lectin receptor sites, it can be assumed that diabetic impairments of rat kidney glycoconjugates includes unmasking of DGal and DGal-NAc residues apparently due to incomplete final glycosylation of carbohydrate determinants.

Among the most characteristic manifestations of diabetic nephropathy was the enhanced lectin reactivity of the brush border within the proximal and distal tubules. Supplemented with the morphometric data, which revealed a direct correlation between diabetes progression and decreased urinary space of both individual renal corpuscles and of the kidney as a whole (unpublished data), it can be speculated that DM may affect active reabsorption in nephron epithelial cells, in compliance with the accumulation of lectin-reactive enzymes in their brush border. 
It is generally accepted that diabetic nephropathy is accompanied by the accumulation of glycogen deposits within the cells of cortical ascending thick limbs $[10,11]$. With reference to the data of Zlotowski et al. [31] on strong glycogen reactivity with Con A, we expected to find considerable enhancement of Con A binding in diabetic rat kidney. On the contrary, the recent observations revealed a diabetes-induced decrease of this lectin reactivity. There can be two possible explanations for this phenomenon: 1) partial extraction of glycogen during formalin fixation and following tissue processing; and 2) Con A receptor sites in rat kidney apparently include, besides glycogen, a vast pool of non-extractable glycoconjugates, which becomes reduced in the condition of experimental diabetes mellitus.

\section{Conclusions}

1. Postnatal morphogenesis of rat kidney is accompanied by exposure of extra DMan, LFuc, and NeuNAc residues, in association with reduction of DGal and DGalNAc sugar determinants. Renal glycoconjugate remodeling in rats lasts up to postnatal day 60 , which corresponds to kidney maturity.

2. Diabetic impairments of rat kidney glycoconjugates include unmasking of DGal and DGalNAc residues, presumably due to incomplete final glycosylation patterns of carbohydrate determinants.

3. Lectins demonstrated selective binding to rat kidney constituents: MPFA, WGA, and RCA - to renal corpuscles; SBA and HPA - to cortical tubules; and WGA and RCA - to the renal tubules of the outer medulla.

4. Original lectin preparations (MPFA, LABA, and LVA) can be recommended for further application in developmental morphology and experimental histopathology research.

\section{Acknowledgements}

The authors would like to thank Dr. Luba Wolchuk and Dr. Anthony Shardt, Visiting Professors at the Lviv National Medical University, for their editorial advice and assistance during the preparation of this paper.

\section{References}

1. Sharon N. Lectins: carbohydrate-specific reagents and biological recognition molecules. J Biol Chem. 2007;282: 2753-2764.
2. Gabius HJ. The sugar code: fundamentals of glycosciences. Weinheim: John Wiley \& Sons; 2009.

3. Varki A, Cummings RD, Esko JD et al. Essentials of glycobiology ( $2^{\text {nd }} e d$.). Cold Springs: Cold Spring Harbor Laboratory Press; 2009.

4. Roth J. Lectins for histochemical demonstration of glycans. Histochem Cell Biol. 2011;136:117-130.

5. Fischer E, Wagner M, Bertsch H. Cepaea hortensis agglutinin-I, specific for O-glycosidically linked sialic acids, selectively labels endothelial cells of distinct vascular beds. Histochem J. 2000;32:105-109.

6. Antonyuk VO, Yashchenko AM, Antonyuk RV, Ambarova NO. Carbohydrate specificity of lectin, purified from the fruiting bodies of Mycena pura /Fr./ Kumm. and its use in histochemical investigation. Biopolym Cell (Kiev). 2009;25: 466-475.

7. Lutsyk MD, Antonyuk VA. New fucose-specific lectin from Laburnum anagyroides bark: purification, properties and immunochemical characteristics. Biochimia (Moscow). 1982;47:1710-1715.

8. Antonyuk LYa. Purification and some properties of lectins from Galantus nivalis L. and Leucojum vernum L. Biochimia (Moscow). 1993;58:367-375.

9. Schulte BA, Spicer SS. Histochemical evaluation of mouse and rat kidneys with lectin-horseradish peroxidase conjugates. Am J Anat. 1983;168:345-362.

10. Rosenquist $\mathrm{TH}$, Huff $\mathrm{T}$. Lectin binding in the diabetic rat kidney. Histochemistry. 1985;8:279-284.

11. Hennigar RA, Mayfield RK, Harvey JN et al. Lectin detection of renal glycogen in rats with short-term streptozotocindiabetes. Diabetologia. 1987;30:804-811.

12. Laitinen L, Virtanen I, Saxen L. Changes in the glycosilation pattern during embryonic development in mouse kidney as revealed with lectin conjugates. $J$ Histochem Cytochem. 1987;35:55-65.

13. Holthofer H, Hennigar RA, Schulte BA. Glomerular sialoconjugates of developing and mature rat kidneys. Cell Differentiation. 1988;24:215-222.

14. Hanai T, Usuda N, Morita T, Nagata T. Light microscopic lectin histochemistry in aging mouse kidney: study of compositional changes in glycoconjugates. J Histochem Cytochem. 1994;42:897-906.

15. Schumacher K, Strehl R, Minuth MM. Detection of glycosylated sites in embryonic rabbit kidney by lectin chemistry. Histochem Cell Biol. 2002;118:79-87.

16. Zuber C, Paulson JC, Toma V et al. Spatiotemporal expression patterns of sialoglycoconjugates during nephron morphogenesis and their regional and cell type-specific distribution in adult rat kidney. Histochem Cell Biol. 2003;120:143-160.

17. Cullen-McEwen LA, Armitage JA, Nyengaard JR et al. A design-based method for estimating glomerular number in the developing kidney. Am J Physiol Renal Physiol. 2011;300: F1448-1453.

18. Kumar AP, Nandini CD, Salimath PV. Structural characterization of $\mathrm{N}$-linked oligosaccharides of laminin from rat kidney: changes during diabetes and modulation by dietary fiber and butyric acid. FEBS Journal. 2011;278:143-155.

19. Maurer G. Disc-electrophoresis. Moscow: Mir; 1971.

20. Nakane PK, Kawaoi A. Peroxidase labeled antibody. A new method of conjugation. J Histochem Cytochem. 1974;22: 1084-1091. 
21. Antonyuk VO, Yashchenko AM. Lectin conjugation with horseradish peroxidase: improvement of method. Clin Lab Diagnostic (Moscow). 1996;3:51-52.

22. Wada R, Yagihashi S. Nitric oxide generation and poly(ADP ribose) polimerase activation precede beta-cell death in rats with a single high-dose injection of streptozotocin. Virchows Arch. 2004;444:375-382.

23. Lutsyk A, Sogomonian E. Structural, functional, and lectin histochemical characteristics of rat ovaries and endometrium in experimental hyper- and hypothyroidism. Folia Histochem Cytobiol. 2012;50:331-339.

24. Debray H, Decout D, Strecker G et al. Specificity of twelve lectins towards oligosaccharides and glycopeptides related to N-glycosylproteins. Eur J Biochem. 1981;117:41-55.

25. Piskariov VE, Lutsyk-Kordovski MD, Piskariova EL, Yamskov IA. Oligosaccharidic specificity of fucolectins from Laburnum anagyroides bark. Prikl Biochim Microbiol (Moscow). 2003;39:512-518.
26. Roth J. Application of lectin-gold complexes for electronmicroscopic localization of glycoconjugates on thin sections. J Histochem Cytochem. 1983;31:987-999.

27. Swamy MJ, Gupta D, Mahanta SK, Surolia A. Further characterization of the saccharide specificity of peanut (Arachis hypogaea) agglutinin. Carbohydr Res. 1991;213:59-67.

28. Piller V., Piller F., Cartron IP. Comparison of the carbohydratebinding specificities of seven N-acethyl-D-galactosamine-recognizing lectins. Eur J Biochem. 1990;191:461-466.

29. Shibuya N, Goldstein IJ, Broekaert WF et al. The elderberry (Sambucus nigra L.) bark lectin recognizes the Neu5Ac (a2-6)Gal/GalNAc sequence.J Biol Chem. 1987;262:1596-1601.

30. Bhavanandan VP, Katlic AW. The interaction of wheat germ agglutinin with sialoglycoproteins. The role of sialic acid. J Biol Chem. 1979;254:4000-4008.

31. Zlotowski P, Gimeno EJ, Diaz A et al. Lectin histochemistry: glycogenosis in cattle. Vet Res Commun. 2006;30:369-377.

Submitted: 15 November, 2012 Accepted after reviews: 8 March, 2013 